\title{
Pengaruh Faktor Internal, Sanksi dan Modernisasi Administrasi Perpajakan Terhadap Kepatuhan Wajib Pajak Badan
}

\author{
(The Influence of Internal Factors, Sanction and Modernization Tax \\ Administration on Corporate Taxpayer Compliance)
}

Oleh:

\author{
Emmelia Tan'); Alin Ananda Pradita ${ }^{2)}$ \\ Universitas Pelita Bangsa1,2) \\ Emmelia.tan@pelitabangsa.ac.id ${ }^{12}$
}

$\begin{array}{llll}\text { Submit: } 10 \text { Aug } 2020 \quad \text { Review: } 23 \text { Aug } 2020 \quad \text { Accept: } 25 \text { Aug } 2020 & \text { Publish: } 26 \text { Aug } 2020\end{array}$

\begin{abstract}
ABSTRAK
Penelitian ini dilakukan untuk menganalisa pengaruh kesadaran wajib pajak, sanksi pajak, pengetahuan pajak, kondisi keuangan, dan modernisasi administrasi keuangan terhadap kepatuhan wajib pajak badan di wilayah kerja KPP Cikarang Selatan dan Cikarang Utara. Responden dalam penelitian ini adalah 103 karyawan pajak perusahaan wilayah KPP Cikarang sebagai pegawai profesional dan telah bekerja minimal 1 yang dapat mewakili perusahaan dalam perpajakan. Metode analisis yang digunakan adalah Regresi Linear Berganda dengan SPSS. Hasil penelitian secara t-test menunjukan bahwa independen variable yaitu (1) kesadaran wajib pajak (2) pengetahuan perpajakan (3) kondisi keuangan, dan (4) modernisasi administrasi perpajakan berpengaruh terhadap kepatuhan wajib pajak, sedangkan (5) sanksi pajak tidak berpengaruh terhadap kepatuhan wajib pajak.
\end{abstract}

Kata kunci:

Kesadaran; Sanksi; Pengetahuan; Kondisi Keuangan; Modernisasi Administrasi; Kepatuhan; Wajib Pajak Badan

\section{ABSTRACT}

This study aims to analyze the effect of tax awareness, tax sanction, tax knowledge, financial condition, $\mathcal{E}$ modernized tax administration on corporate taxpayer compliance. The survey was conducted under the territory area of KPP Cikarang Selatan and Cikarang Utara. Respondents in this study were professional tax officer who had worked for at least 1 year and can be as representative for handling taxation for their company. This analysis method using Multiple Linear Regression by SPSS. Based on the results t-test showed that tax awareness, tax knowledge, financial conditions, and modernized tax administration partially have an influence on corporate taxpayer compliance, while tax sanctions don't have an influence on corporate taxpayer compliance.

Keywords:

Tax, Awareness; Sanction; Knowledge; Financial Condition; Modernized Tax Administration; Corporate Taxpayer, Compliance 


\section{PENDAHULUAN}

Dewan Perwakilan Rakyat menetapkan alokasi belanja Negara di tahun anggaran 2018 sebesar Rp 2.220,66 triliun dan target penerimaan perpajakan dipatok Rp 1.618,09 triliun, sehingga kontribusi penerimaan perpajakan terhadap APBN mencapai $72,86 \%$ (Bastanul, 2018). Realisasi penerimaan pajak untuk tahun 2018 sebesar Rp 1.315,9 triliun, menurut laporan kemenkeu terjadi peningkatan pertumbuhan penerimaan pajak walaupun target tidak tercapai dari target awal APBN 2018. Masyarakat umum yang ingin mengetahui ke mana uang pajak dan alokasi pajak dapat melihat di https:// www.kemenkeu.go.id/alokasipaj akmu. Dalam simulasi ini, uang pajak yang dibayar, bersifat akumulatif yaitu perhitungan penerimaan perpajakan dari PPh, PPN, PPnBM, cukai, bea masuk, bea keluar, bea materai dan PBB Migas. Dijelaskan alokasi uang pajak atau kontribusi wajib pajak dalam Belanja Pemerintah Pusat menurut fungsinya, yaitu pelayanan umum, pertahanan, ketertiban dan keamanan, ekonomi, perlindungan lingkungan hidup, perumahan dan fasilitas umum, kesehatan, pariwisata, agama, pendidikan, dan perlindungan sosial. Alokasi kontribusi pajak dalam belanja ke pemerintah daerah yaitu : Dana alokasi umum, Dana bagi hasil, Dana Alokasi Khusus Fisik, Dana Alokasi khusus nonfisik, Dana Keistimewaan DIY, Dana otonomi khusus, Dana insentif ke daerah, Dana desa.

Indonesia sudah menganut dan menerapkan sistem Self Assesment sejak tahun 1984 sampai sekarang. Self Assesment itu sendiri merupakan sistem kepercayaan penuh kepada Wajib Pajak Pribadi atau Badan Usaha untuk menghitung, membayar dan melaporkan perpajakannya kepada pihak Kantor Pajak.
Dalam sistem ini saling percaya dan kerjasama antara wajib pajak dan petugas pajak adalah sangat penting, jika ada saling percaya, maka wajib pajak akan bersikap positif terhadap sistem perpajakan, petugas pajak dan mau bekerjasama dengan baik (Daare, 2017).

Kepatuhan wajib pajak adalah kondisi ideal secara akurat dan jujur mau memenuhi peraturan perpajakan serta melaporkan penghasilannya, tingkat kepatuhan perpajakan secara sukarela memiliki tiga aspek yaitu aspek formal, material (honestly) dan pelaporan (reporting) (Harinurdin, 2009). Kesadaran dan kepatuhan wajib pajak merupakan faktor penting bagi peningkatan penerimaan pajak, maka perlu secara rutin dikaji tentang faktor-faktor yang mempengaruhi kepatuhan wajib pajak (Aini, et.al. 2014).

Menurut Manik (2009 dalam Muliari \& Setiawan, 2011) wajib pajak memiliki kesadaran perpajakan apabila: mengetahui adanya undang-undang dan ketentuan perpajakan; mengetahui fungsi pajak untuk pembiayaan Negara; memahami kewajiban perpajakan sesuai ketentuan yang berlaku; dan menghitung, membayar, melaporkan pajak secara sukarela dan benar. Kesadaran untuk mematuhi ketentuan (Hukum Pajak) yang berlaku tentu menyangkut faktor-faktor apakah ketentuan tersebut telah diketahui, diakui, dihargai, dan di taati. Bila seseorang hanya mengetahui, berarti kesadaran wajib pajak tersebut masih rendah. Kesadaran wajib pajak adalah suatu kondisi dimana wajib pajak mengetahui, memahami, dan melaksanakan ketentuan-ketentuan perpajakan dengan benar dan sukarela. Pengetahuan dan pemahaman tentang perpajakan sangat penting karena dapat membantu wajib pajak dalam mematuhi aturan perpajakan. Putri\& Septriana (2020) 
mengajukan hipotesis kesadaran perpajakan akan berpengaruh positif signifikan terhadap kepatuhan pajak, semakin tinggi kesadaran perpajakan akan semakin besar kepatuhannya.

Sanksi Pajak menurut Mardiasmo (2009) menyatakan bahwa sanksi perpajakan merupakan jaminan bahwa ketentuan peraturan perundang-undangan perpajakan (norma perpajakan) akan dituruti, ditaati, dipatuhi. Atau dengan kata lain sanksi perpajakan merupakan alat pencegah (preventif) agar wajib pajak tidak melanggar norma-norma perpajakan. Sanksi pajak menurut Nugroho (2006 dalam Muliari \& Setiawan, 2011) dianggap akan lebih banyak merugikan sehingga wajib pajak akan memenuhi kewajiban perpajakan dengan patuh

Pengetahuan Pajak menurut Harris (1989 dalam Andreas \& Savitri, 2015) menjelaskan "Pengetahuan pajak dibagi dua aspek yaitu pengetahuan melalui pengalaman atau pendidikan formal yang diterima sebagai suatu pengetahuan khususnya masalah mengarah kepada kemungkinan kesempatan untuk menghindari pajak". Septyana \& Suprasto (2019) juga mengaskan pentingnya pengetahuan perpajakan bagi wajib pajak untuk memahami penerapan ketentuan perpajakan untuk melaksanakan kewajiban perpajakan dengan tepat dan benar, diiringi dengan peran penting petugas pajak dalam meningkatkan pengetahuan perpajakan melalui sosialisasi atau training.

Kondisi Keuangan mencerminkan kinerja dan tingkat kesehatan keuangan perusahaan tercermin dalam tingkat profitabilitas baik dan arus kas yang likuid. Perusahaan dengan kriteria tersebut cenderung melaporkan pajak dengan jujur dan mematuhi pembayaran pajak secara tepat waktu dan tingkat kepatuhan pajaknya baik (Setiawan, 2013). Aini et al,. (2014) menjelaskan perusahaan yang mengalami kesulitan likuiditas dalam upaya mempertahankan arus kas, akan ada kemungkinan tidak mematuhi peraturan perpajakannya.

Program reformasi administrasi perpajakan dinyatakan didalam sistem administrasi perpajakan yang modern melalui pembentukan account representative dan complaint center, pengembangan Sistem Administrasi Perpajakan Terpadu (SAPT) dikontrol oleh case management system dengan modul otomasasi dan pelayanan berbasis e-system (e-SPT, e-Filling, ePayment, Taxpayer's Account, e-Registration, e-Counceling) ditambah adanya kode etik pagawai Direktorat Jenderal Pajak. Modernisasi perpajakan dengan pelayanan yang baik, pengawasan dan pelaksanaan good governance meningkatkan kepatuhan pajak dan kepercayaan terhadap administrasi perpajakan. (Rahayu \& Lingga, 2009). Eka (2019) meneliti reformasi administrasi perpajakan orang pribadi mempunyai pengaruh positif signifikan kepatuhan wajib pajak. Rahman (2014) mengajukan model penelitian pengaruh modernisasi administrasi perpajakan terhadap kepatuhan wajib pajak baik secara langsung dan tidak langsung dengan varibel perantara sanksi pajak, moral pajak dan pelayanan pajak.

Penelitian terdahulu yang mempelajari faktor-faktor yang mempengaruhi kepatuhan wajib pajak badan oleh Sucandra, L. K. I. P., \& Supadmi, N. L. (2016) memakai faktor pengaruh yaitu kualitas pelayanan, pemeriksaan pajak, pengetahuan perpajakan dan sanksi perpajakan, dan hasil analisa penelitian mereka menunjukkan bahwa keempat faktor mempunyai pengaruh positif dan 
signifikan terhadap wajib pajak badan restoran di DPD Agung Kab. Badung, Bali. Muliari, N. K., \& Setiawan, P. E. (2011) meneliti pengaruh persepsi sanksi perpajakan dan kesadaran wajib pajak pada kepatuhan pelaporan wajib pajak orang pribadi di KPP Denpasar Timur, hasil penelitian menunjukkan kedua faktor secara simultan mempunyai pengaruh positif dan signifikan. Rahayu, S., \& Lingga, I. S. (2009) meneliti pengaruh modernisasi sistem administrasi perpajakan terhadap kepatuhan wajib pajak badan pada KPP Bandung " $X$ " dan hasil penelitian menunjukkan pengaruh positif dan signifikan. Sebuah penelitian meta analisis oleh Assan \& Damayanti, (2017) tentang kepatuhan wajib pajak badan di Indonesia dari artikel yang dipublikasi selama tahun 2004-2015 menemukan bahwa modernisasi administrasi pajak, sanksi pajak, kualitas pelayanan, dan pengetahuan akuntansi pajak dan pemeriksaan pajak mempunyai pengaruh signifikan dalam kepatuhan wajib pajak badan. Penelitian ini ada sedikit berbeda dengan penelitian sebelumnya, memakai faktor pengaruh kesadaran wajib pajak, sanksi pajak, pengetahuan pajak, kondisi keuangan perusahaan dan modernisasi administrasi perpajakan untuk meneliti pengaruh kepatuhan wajib pajak badan di area KPP Cikarang selatan dan Cikarang utara, Kab. Bekasi.

\section{METODE PENELITIAN}

Penelitian dilakukan di wilayah KPP Cikarang Selatan dan KPP Cikarang Utara kepada 103 staf pajak yang bekerja di perusahaan yang terdaftar dalam wilayah KPP tersebut. Penelitian dilakukan dengan membagi kuesioner sesuai proksi dari sumber referensi jurnal dengan jawaban yang didapatkan dalam pilihan 5 poin skala likert pada akhir tahun 2018. Hubungan variabel yang dipergunakan terlihat dalam gambar 1 Desain Kerangka Konsep Penelitian.

Software yang digunakan dalam mengolah data hasil kuesioner diolah dalam program SPSS versi 22. Langkah awal dilakukan uji instrumen penelitian melalui uji Validitas dan Reliabilitas. Uji validitas dilakukan dengan menggunakan teknik korelasi product moment dari Pearson. Uji reliabilitas dilakukan untuk mengetahui sejauh mana kuesioner dapat dipercaya atau dapat diandalkan. Untuk mengukur reliabilitas digunakan nilai cronbach alpha. Jika nilai cronbach alpha lebih besar dari 0,6, dan nilai cronbach alpha if item deleted pada masingmasing pertanyaan < cronbach alpha, maka kueisioner dikatakan reliabel.

Analisis utama yang digunakan adalah analisis regresi linier ganda. Analisis regresi linear berganda dalam penelitian ini untuk mengetahui apakah ada pengaruh dari variabel independen terhadap variabel dependen.

Analisis diawali uji asumsi klasik untuk mengetahui apakah data sampel berdistribusi normal (normalitas), uji multikolinearitas, dan uji heterokedastisitas. Uji normalitas One Sample Kolmogorov-Smirnov yaitu pengujian tentang kenormalan distribusi data pada variable dependen dan variable independen. Uji Multikolinearitas dengan nilai VIF dimana jika VIF < 10 maka masing-masing variabel bebas tidak memiliki hubungan multikolinearitas. Pengujian heteroskedostisitas dilakukan menggunakan scatterplot dengan melihat titik-titik menyebar merata diatas dan dibawah angka 0 (nol) pada sumbu $Y$ dimana persyaratan terpenuhi jika grafik tidak membentuk pola yang jelas. 
Analisis dilanjutkan dengan uji model (goodness of fit test) dengan mendasarkan pada nilai koefisien determinasi dan uji-F. Setelah semua terpenuhi langkah terakhir adalah pengujian hipotesis menggunakan model persamaan regresi linier ganda dan uji-t.

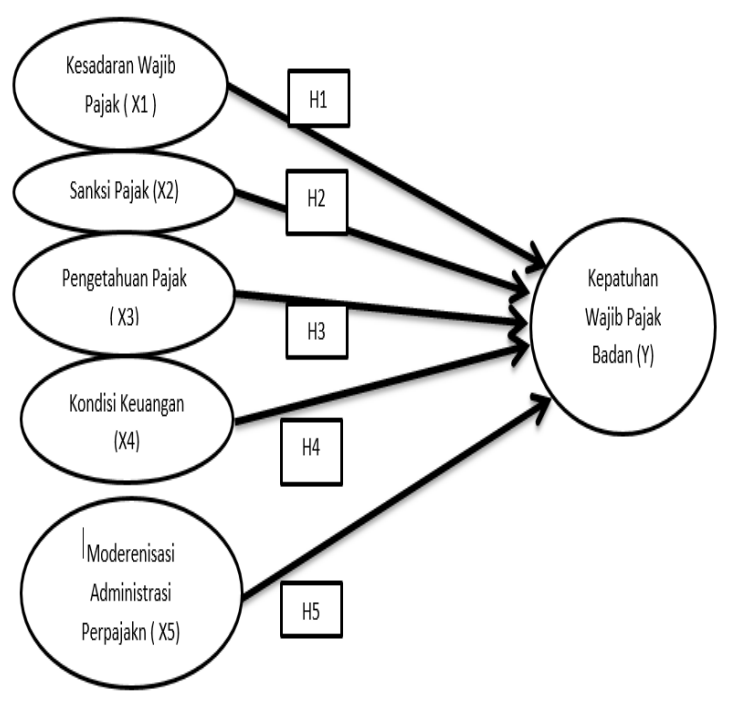

Gambar 1. Kerangka Konsep Penelitian

\section{HASIL PENELITIAN}

\section{Uji Validitas dan Reliabilitas}

Berdasarkan hasil pada uji validitas disimpulkan bahwa untuk semua variabel Kepatuhan Wajib Pajak (Y) sudah didapatkan nilai korelasi product moment pearson di tiap item pertanyaan yang lebih besar dari 0,165 setelah satu instrument dihapus. Dengan demikian dapat disimpulkan bahwa semua item pertanyaan di tiap variabel Kepatuhan Wajib Pajak (Y) sudah valid. Independen variabel Kesadaran Wajib Pajak, Sanksi Pajak, Pengetahuan Perpajakan, Kondisi Keuangan, dan Modernisasi Administrasi Perpajakan dalam penelitian ini memiliki nilai $r$ hitung $>0,165$.
Tabel 1. Tabel Uji Validitas

\begin{tabular}{ccc}
\hline Variabel & Item & Keterangan \\
\hline X1 & 7 & Valid \\
X2 & 4 & Valid \\
X3 & 7 & Valid \\
X4 & 4 & Valid \\
X5 & 5 & Valid \\
Y & 4 & Valid \\
\hline
\end{tabular}

Hasil uji reliabilitas menunjukkan satu variable dependen dan lima variabel independen yang dijadikan instrumen dalam penelitian ini menunjukkan nilai Cronbach alpha diatas 0,6 , sehingga dapat disimpulkan kuesioner pada masingmasing variabel penelitian dapat dinyatakan telah handal dan konsisten. Dengan demikian hasil tersebut semua variable sudah memenuhi syarat reliabilitas dan dapat dilanjutkan analisa penelitian.

Tabel 2. Tabel Uji Realibilitas

Variabel Cronbach Alpha Keterangan

\begin{tabular}{ccl}
\hline X1 & 0,736 & Realiabel \\
X2 & 0,639 & Realiabel \\
X3 & 0,746 & Realiabel \\
X4 & 0,821 & Realiabel \\
X5 & 0,723 & Realiabel \\
Y & 0,634 & Realiabel
\end{tabular}




\section{Uji Asumsi Klasik}

Hasil uji normalitas dalam Tabel 3 melalui nilai $\mathrm{p}$ atau nilai Asymp Sig (2tailed) dari One Sample KolmogorovSmirnov Test adalah $0,00(\mathrm{p}<0,005)$ yang artinya Variabel $\mathrm{Y}, \mathrm{X} 1, \mathrm{X} 2, \mathrm{X} 3, \mathrm{X} 4$, dan $\mathrm{X} 5$ berdistribusi normal.

Tabel 3. Uji Normalitas One Sample KS

\begin{tabular}{|c|c|c|c|c|c|c|c|}
\hline & & $\begin{array}{c}\text { Kepatuha } \\
\text { n Wajib } \\
\text { Pajak }\end{array}$ & $\begin{array}{c}\text { Kesadara } \\
\text { nWajib } \\
\text { Pajak }\end{array}$ & $\begin{array}{c}\text { Sank } \\
\text { si } \\
\text { Pajak }\end{array}$ & $\begin{array}{l}\text { Pengetahu } \\
\text { an Pajak }\end{array}$ & $\begin{array}{c}\text { Kondisi } \\
\text { Keuanga } \\
\text { n }\end{array}$ & $\begin{array}{c}\text { Administra } \\
\text { si } \\
\text { Perpajaka } \\
n\end{array}$ \\
\hline \multicolumn{2}{|l|}{$\mathrm{N}$} & 103 & 103 & 103 & 103 & 103 & 103 \\
\hline \multirow{2}{*}{$\begin{array}{l}\text { Normal } \\
\text { Parameters } \\
\mathrm{a}, \mathrm{b}\end{array}$} & Mean & 18,93 & 26,49 & 26,62 & 26,50 & 13,47 & 22,89 \\
\hline & $\begin{array}{l}\text { Std. } \\
\text { Deviatio } \\
n\end{array}$ & 1,901 & 3,651 & 3,036 & 3,968 & 3,386 & 3,190 \\
\hline \multirow{3}{*}{$\begin{array}{l}\text { Most } \\
\text { Extreme } \\
\text { Differences }\end{array}$} & $\begin{array}{l}\text { Absolut } \\
\mathrm{e}\end{array}$ & ,223 & 139, & ,113 & 161, & 131, &, 179 \\
\hline & Positive & 132, & 106, & 065, & 080, & ,095 & 107 \\
\hline & $\begin{array}{l}\text { Negativ } \\
\mathrm{e}^{-}\end{array}$ & -223 & ; 139 & ;113 &,- 161 & ; 131 & ; 179 \\
\hline \multicolumn{2}{|c|}{ Test Statistic } &, 223 & ,139 &, 113 & , 161 & 131 &, 179 \\
\hline \multicolumn{2}{|c|}{ Asymp. Sig. (2-tailed) } &, $000^{\circ}$ &, $000^{\circ}$ &, $003^{c}$ &, $000^{\circ}$ &, $000^{\circ}$ &, $000^{\circ}$ \\
\hline
\end{tabular}

Hasil ini menunjukan bahwa model penelitian ini memenuhi uji asumsi multikolinieritas.

Tabel 4. Uji Multikolinearitas

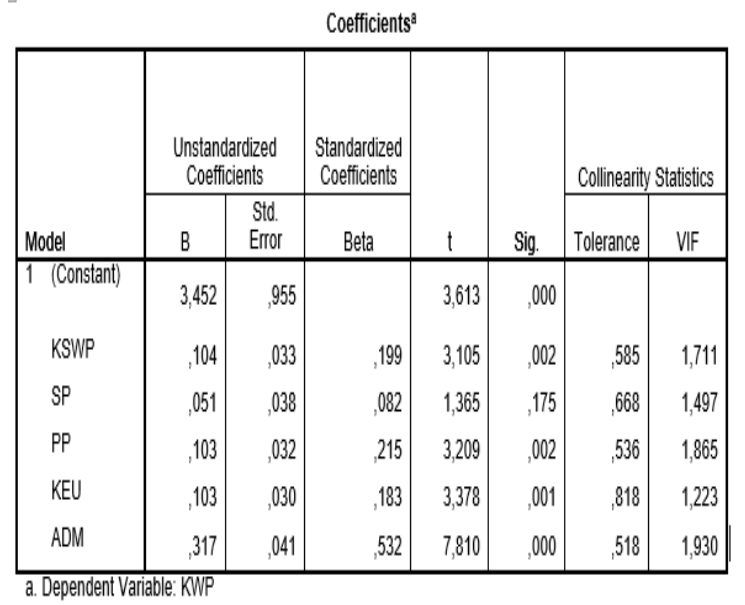

Hasil pengujian heteroskedostisitas melalui scatterplot menunjukan titik-titik menyebar merata diatas dan dibawah angka 0 (nol) pada sumbu Y, walaupun ada garis tertentu tetapi tidak jelas sehingga bisa disimpulkan model memenuhi syarat uji heterokedastisitas.

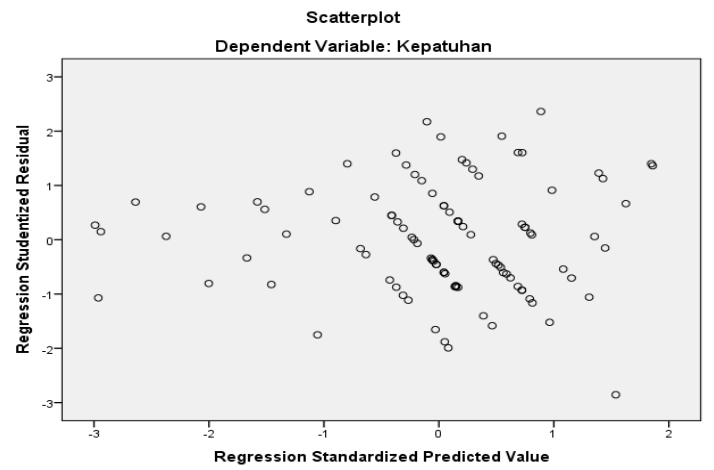

Gambar 2. Output Scatterplot SPSS

\section{Goodness of Fit}

Adjusted R Square $=0,767$ yang berarti variabel Kesadaran Wajib Pajak, Sanksi Pajak, Pengetahuan Perpajakan, Kondisi Keuangan dan Modernisasi Administrasi Perpajakan secara bersama dapat menjelaskan dan memberikan pengaruh sebesar 76,7 \% terhadap Kepatuhan Wajib Pajak Badan.

Tabel 6. Hasil Uji R

Model Summary

\begin{tabular}{|c|c|c|c|c|}
\hline Model & $\mathrm{R}$ & $\begin{array}{c}\mathrm{R} \\
\text { Square }\end{array}$ & $\begin{array}{l}\text { Adjusted R } \\
\text { Square }\end{array}$ & $\begin{array}{l}\text { Std. Error } \\
\text { of the } \\
\text { Estimate }\end{array}$ \\
\hline 1 &, $876^{a}$ & 767, & 755, & 941 \\
\hline
\end{tabular}

Tabel 7. Hasil Anova

ANOVA $^{a}$

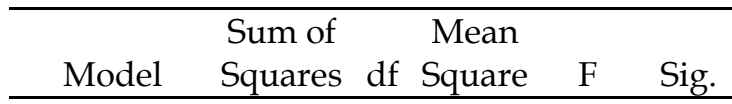

Regression 282,590 $5 \quad 56,518 \quad 63,796,000^{\mathrm{b}}$

1 Residual 85,934 97 ,886

Total 368,524 102

a. Dependent Variable: Kepatuhan Wajib Pajak

b. Predictors: (Constant), Administrasi Perpajakan, Kondisi Keuangan, Sanksi Pajak, Kesadaran Wajib Pajak, Pengetahuan Pajak 
F-test digunakan untuk menguji pengaruh variabel independen secara bersama-sama terhadap variable dependen. Dengan tingkat kepercayaan 0,05 dengan df $1=\mathrm{k}-1=5$ dan df $2=\mathrm{n}-\mathrm{k}-1$ $=103-5-1=97$ diperoleh $\mathrm{F}$ tabel sebesar 2,3082. Dari hasil tabel 7 terlihat F hitung $>$ F tabel atau 63,796 $>2,3082$, sehingga dapat disimpulkan variabel Kesadaran Wajib Pajak, Sanksi Pajak, Pengetahuan Perpajakan, Kondisi Keuangan, dan Modernisasi Administrasi Perpajakan secara bersama-sama mempunyai pengaruh terhadap Kepatuhan Wajib Pajak Badan di KPP Cikarang.

\section{Pengujian Hipotesis}

Hasil regresi linear berganda terlihat dalam tabel dibawah.

Tabel 5. Hasil Analisis Regresi Uji t

Coefficients $^{\mathrm{a}}$

\begin{tabular}{|c|c|c|c|c|c|c|}
\hline \multirow{2}{*}{\multicolumn{2}{|c|}{ Model }} & \multicolumn{2}{|c|}{ Unstandardized Coefficients } & \multirow{2}{*}{$\begin{array}{l}\text { Standardized } \\
\text { Coefficients } \\
\text { Beta }\end{array}$} & \multirow[b]{2}{*}{ t } & \multirow[b]{2}{*}{ Sig. } \\
\hline & & $B$ & Stat Error & & & \\
\hline 1 & (Constant) & 3,452 & 955 & & 3,013 &, 000 \\
\hline & Kesadaran Waijp Pajak &, 104 &, 033 & 199 & 3,105 &, 002 \\
\hline & SanksiPajak &, 051 &, 038 &, 082 & 1,365 &, 175 \\
\hline & Pengetahuan Pajak &, 103 &, 032 & 215 & 3,209 &, 002 \\
\hline & Kondisi Keuangan &, 103 &, 030 &, 183 & 3,378 &, 001 \\
\hline & Administrasi Perpajakan & 317 &, 041 & 532 & 7,810 &, 000 \\
\hline
\end{tabular}

a. DependentVariable: Kepatuhan Wajib Pajak

Berdasarkan hasil output SPSS regresi linear berganda, maka didapatkan persamaan:

$Y=3,452+0,104 X 1+0,051 X 2+0,103 X 3$

$+0,103$ X4 + 0,317 X5

Keterangan : Y: Kepatuhan Wajib Pajak; X1:

Kesadaran wajib; X2: Sanksi pajak; X3: Pengetahuan perpajakan; X4: Kondisi keuangan; X5: Modernisasi administrasi perpajakan
Berdasarkan Uji $t$ regresi linear berganda dalam tabel 5, probabilitas signifikansi untuk variabel kesadaran wajib pajak terhadap kepatuhan wajib pajak $t$ sig. sebesar 0,002, untuk variabel sanksi pajak t sig. sebesar 0,175, untuk variabel pengetahuan perpajakan $t$ sig. sebesar 0,002, untuk kondisi keuangan sebesar 0,001, dan untuk variabel modernisasi administrasi $t$ sig. sebesar 0,000. Oleh karena nilai probabilitas signifikansi variabel kesadaran wajib pajak, pengetahuan perpajakan, kondisi keuangan dan modernisasi perpajakan dibawah nilai probabilitas signifikansi $\alpha=$ 0,005 ini berarti variabel tersebut secara individual mempunyai pengaruh signifikan terhadap kepatuhan wajib pajak badan. Sedangkan untuk variabel sanksi pajak karena memiliki nilai $\mathrm{t}$ sig sebesar 0,175 atau diatas $\alpha=0,005$, sehingga secara individual tidak memiliki pengaruh signifikan terhadap kepatuhan wajib pajak.

\section{PEMBAHASAN}

Kesadaran wajib pajak berpengaruh positif terhadap kepatuhan wajib pajak badan. Hasil ini konsisten dengan penelitian-penelitian terdahulu seperti Andreas, \& Savitri, E. (2015). Pengetahuan perpajakan berpengaruh positif terhadap kepatuhan wajib pajak badan, sejalan dengan penelitian terdahulu (Sucandra \& Supadmi, 2016; Septyana \& Suprasto, 2019; Andreas \& Savitri, 2015).

Kondisi keuangan berpengaruh positif terhadap kepatuhan wajib pajak badan. Hasil penelitian sejalan dengan penelitian Aini et al,. (2014) yang melakukan penelitian terhadap wajib pajak badan perusahaan manufaktur di Semarang.

Modernisasi administrasi perpajakan mempunyai pengaruh positif terhadap kepatuhan wajib pajak badan di KPP 
Cikarang Selatan dan Cikarang Utara. Hasil penelitian ini sejalan dengan penelitian Rahayu \& Lingga (2009).

Sanksi pajak tidak memiliki pengaruh terhadap kepatuhan wajib pajak badan. Hasil penelitian ini sama dengan hasil penelitian yang dilakukan oleh Priantara \& Supriyadi (2012) yang menyatakan tidak terdapat pengaruh dari penerapan sanksi perpajakan terhadap tingkat kepatuhan pengusaha kecil di Madiun dalam upaya mendaftarkan diri menjadi Wajib Pajak.

Demikian juga, Meidawati \& Azmi (2019) yang melakukan penelitian terhadap wajib pajak orang pribadi yang menjalankan usaha di area KPP Pontianak, mendapatkan hasil penelitian faktor yang positif terhadap kepatuhan pajak adalah kesadaran wajib pajak, sedangkan pengetahuan pajak dan sanksi pajak tidak memiliki pengaruh.

Kepatuhan Wajib Pajak Badan di KPP Cikarang dikontribusi dengan positif oleh adanya faktor Kesadaran wajib pajak, Pengetahuan Pajak, Kondisi Keuangan Perusahaan dan Modernisasi administrasi perpajakan. Diantara keempat faktor tersebuat pengaruh yang paling besar yaitu adanya kemudahan dalam modernisasi administrasi perpajakan oleh sistem DJP beberapa tahun terakhir, WP Badan merasa sangat terbantu dengan modernisasi sistem ini dalam penghitungan, pelaporan pajak ditambah data pajak yang terintegrasi online. Sosialisasi dan training yang diadakan secara berkala oleh KPP terhadap WP Badan juga sangat penting dalam menumbuhkan Kepatuhaan Perpajakan WP. Kontribusi koefisien positif yang hampir sama untuk masing-masing variabel Kesadaran Wajib Pajak,
Pengetahuan Pajak dan Kondisi Keuangan Perusahaan. Penelitian ini menemukan sanksi pajak tidak berpengaruh signifikan terhadap Kepatuhan Wajib Pajak Badan di KPP Cikarang, hal ini disebabkan karena WP Badan sudah memiliki pengetahuan perpajakan yang cukup mumpuni dan kesadaran akan konsekuensi dari transaksi kelalaian perpajakannya. Misal jika WP Badan ada telat bayar atau belum membayar kewajiban pajaknya, maka WP Badan sudah tahu sanksi berikut dengan berapa besar dendanya yang akan diterima ke depan.

\section{KESIMPULAN}

Kepatuhan Wajib Pajak Badan di KPP Cikarang dikontribusi dengan positif oleh adanya faktor Kesadaran wajib pajak, Pengetahuan Pajak, Kondisi Keuangan Perusahaan dan Modernisasi administrasi perpajakan. Diantara keempat faktor tersebuat pengaruh yang paling besar yaitu modernisasi administrasi perpajakan. Kontribusi koefisien positif yang hampir sama untuk masing-masing variabel Kesadaran Wajib Pajak, Pengetahuan Pajak dan Kondisi Keuangan Perusahaan. Sanksi pajak tidak berpengaruh terhadap Kepatuhan Wajib Pajak Badan.

Penelitian selanjutnya diharapkan bisa mengembangkan model penelitian dengan menambah atau merevisi variabel independen menjadi variabel perantara. Sampel penelitian bisa lebih dikhususkan lagi misal Kepatuhan WP UMKM atau pengusaha WP orang pribadi. Penelitian selanjutnya juga disarankan bisa bekerjasama dengan KPP dalam melakukan survey penelitian. 


\section{PUSTAKA}

Aini, A. O., Budiman, J., \& Wijayanti, P. (2014). Kepatuhan Wajib Pajak Badan Perusahaan Manufaktur di Semarang Dalam Perspektif Tax Professional. InFestasi (Jurnal Bisnis dan Akuntansi), 10(1), 22-35.

Andreas, \& Savitri, E. (2015). The Effect of Tax Socialization, Tax Knowledge, Expediency of Tax ID Number and Service Quality on Taxpayers Compliance with Taxpayers Awareness as Mediating Variables. Procedia - Social and Behavioral Sciences, 211(September), 163-169. https://doi.org/10.1016/j.sbspro.2015.11.024

Assan, A. E., \& Damayanti, T. W. (2017). Analisis Kepatuhan Wajib Pajak Badan di Indonesia: Sebuah Meta Analisis. 17(2), 139-152.

Bastanul Siregar (2018). Ke Mana Sebenarnya Uang Pajak Kita. Dalam Darussalam, Danny Septriadi, B. Bawono Kristiaji, dan Khisi Armaya Dhora (ed.). Seri Kontribusi DDTC: Gagasan dan Pemikiran Sektor Perpajakan 2018/2019.

Daare, N. A. and W. J. (2017). Tax awareness and perception of tax payers and their voluntary tax compliance decision: Evidence from inividual tax payers in SNRR, Ethopia. International Journal of Scientific and Research Publications, 7(11), 686. www.ijsrp.org

Eka, I. W. A. (2019). the Impact of the Indonesian Tax Administration Reform on Tax Compliance and Tax Revenue. Jurnal Ekonomi Pembangunan, 27(1), 1-24. https:/ / doi.org/10.14203/jep.27.1.2019.1-24

Harinurdin, E. (2009). Perilaku Kepatuhan Wajib Pajak Badan. Jurnal Ilmu Administrasi Dan Organisasi, 16(2), 96-104.

Mardiasmo. (2009). Perpajakan. Yogyakarta: Penerbit Andi.

Meidawati, N., \& Azmi, M. N. (2019). Factors influencing the compliance of taxpayers. Journal of Contemporary Accounting, 1(1), 26-37. https:/ / doi.org/10.20885/jca.vol1.iss1.art3

Muliari, N. K., \& Setiawan, P. E. (2011). Pengaruh Persepsi Tentang Sanksi Perpajakan Dan Kesadaran Wajib Pajak Pada Kepatuhan Pelaporan Wajib Pajak Orang Pribadi Di Kantor Pelayanan Pajak Pratama Denpasar Timur. Jurnal Ilmiah Akuntansi Dan Bisnis, 1-23.

Putri, B. N., \& Septriana, I. (2020). Tingkat Kepatuhan Wajib Pajak Badan dalam Memenuhi Kewajiban Perpajakannya Melalui Pemeriksa Pajak, Kesadaran dan Kualitas Pelayanan pada KPP Pratama Semarang Barat. Jurnal Penelitan Ekonomi dan Bisnis, 5(1), 1-15.

Priantara, D., \& Supriyadi, B. (2012). Faktor-faktor yang Mempengaruhi Pengusaha Kecil dan Mikro Mendaftar Menjadi Wajib Pajak Orang Pribadi. Jurnal Akuntansi Dan Keuangan, 13(2), 98-107. https://doi.org/10.9744/jak.13.2.98-108

Rahayu, S., \& Lingga, I. S. (2009). Pengaruh Modernisasi Sistem Administrasi Perpajakan Terhadap Kepatuhan Wajib Pajak (Survei Atas Wajib Pajak Badan Pada KPP Pratama Bandung "X"). Jurnal Akuntansi, 1(2), 119-138. https:/ / doi.org/10.28932/jam.v1i2.375

Rahman, A. (2014). Measuring The Impact Of Modernized Tax Administration System On Tax Compliance By Tax Sanction, Tax Morale, And Tax Service As Intervening Variables. None, 20(3), 115-125.

Septyana, K. P., \& Suprasto, H. B. (2019). Effect of taxation knowledge, fiscus service, and tax sanctions on tax obligation compliance with tax amnesty as moderated variables. International Research Journal of Management, IT and Social Sciences, 6(6), 111-117. https://doi.org/10.21744/irjmis.v6n6.773 
Setiawan, P. A. (2013). Analisis Faktor-Faktor Yang Mempengaruhi Kepatuhan Wajib Pajak Badan Pada Perusahaan Perhotelan Di Kota Surakarta. https://doi.org/10.1017/CBO9781107415324.004 